\title{
An Asymmetric Synthetic Approach to the A-ring of the Taxol Family of Anti-Cancer Compounds*
}

\author{
D. Craig** and M. L. Marin
}

Department of Chemistry, Imperial College of Science, Technology and Medicine, London SW7 2AY, UK

Tel. +44 171 5945771; Fax:+44 171 5945804; e-mail: dcraig@ic.ac.uk

Received: 10 January 1998 / Accepted: 16 January 1998 / Published: 20 February 1998

\begin{abstract}
A synthetic route developed for the preparation of the A-ring of Taxol family of molecules is reported. By means of an intramolecular Diels-Alder reaction an asymmetric approach to this ring has been accomplished. Also, initial studies to prepare the A ring using an intramolecular Diels-Alder reaction have been successful.
\end{abstract}

Keywords: Taxol, cation-mediated cascade cyclisation, asymmetric Diels-Alder reaction

\section{Introduction}

The Taxol® family of molecules, exemplified by Taxol [1], and baccatin III (Figure 1) has commanded the attention of some of the most eminent synthetic organic research teams in the world [2]. This intense interest has been engendered by the unusual tetracyclic structure of this class of compounds, and more importantly, by the use of Taxol in cancer chemotherapy. This outstanding combination of attractive features has stimulated a huge variety of synthetic approaches directed towards the synthesis of Taxol itself, and simpler analogues which may also have desirable anti-cancer properties.

We proposed a versatile strategy for Taxol synthesis in which two major fragments are coupled at a late stage in the synthetic sequence (Scheme 1). Our approach is unique in that the C-3-C-4 and C-8-C-9 bonds are formed from a cyclisation precursor containing an intact D-ring.

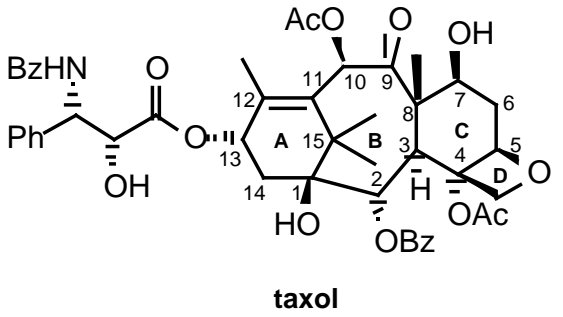

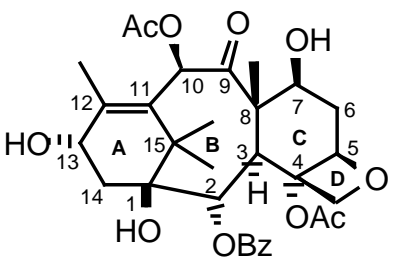

Figure 1. baccatin III

\footnotetext{
* This paper was presented at ECSOC-1, http://www.mdpi.org/ecsoc-1.htm, 1-30 September 1997.

** To whom correspondence should be addressed.
}

(C) 1998 MDPI. All rights reserved. Molecules website http://www.mdpi.org/molecules/ 
The inception of this approach is based on previously developed Diels-Alder chemistry within the Craig group [3], especially in the context of tethered intramolecular (IMDA) cycloadditions [4], and on the studies of cationmediated intramolecular C-glycosidation processes [5]. Thus, the B- and C-rings are closed in a single step on the coupled product 1 via cation-mediated cascade cyclisation. This precursor $\mathbf{1}$ is obtained by coupling the A,B-ring (2) and the C,D-ring (3) fragments.

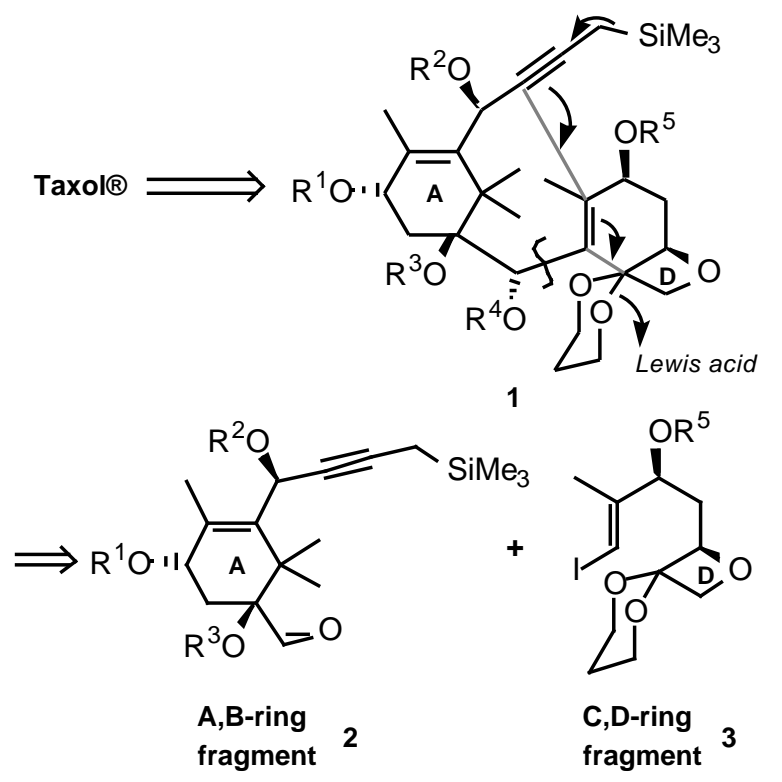

Scheme 1.

\section{Results and Discussion}

In this paper we report studies of a synthetic approach to the A-ring fragment 2 . The retrosynthetic analysis we proposed for this fragment is shown in Scheme 2. The side chain on C-11 of fragment 2 would be introduced by a nucleophilic addition to an aldehyde moiety existing on this carbon in the cyclohexane 4. This intermediate would be the result of a Diels-Alder reaction between the diene $\mathbf{5}$ and a suitable dienophile. In order to accomplish an asymmetric approach to the A,B-ring fragment we proposed to prepare chiral dienes and attempt Diels-Alder reactions with relatively simple dienophiles. These asymmetric dienes $\mathbf{5}$ would be available by a Julia olefination reaction between the asymmetric sulfones 6 and the aldehyde 7 .

Therefore, the synthesis began with the preparation of the aldehyde 7 from the commercially available solketal (Scheme 3).
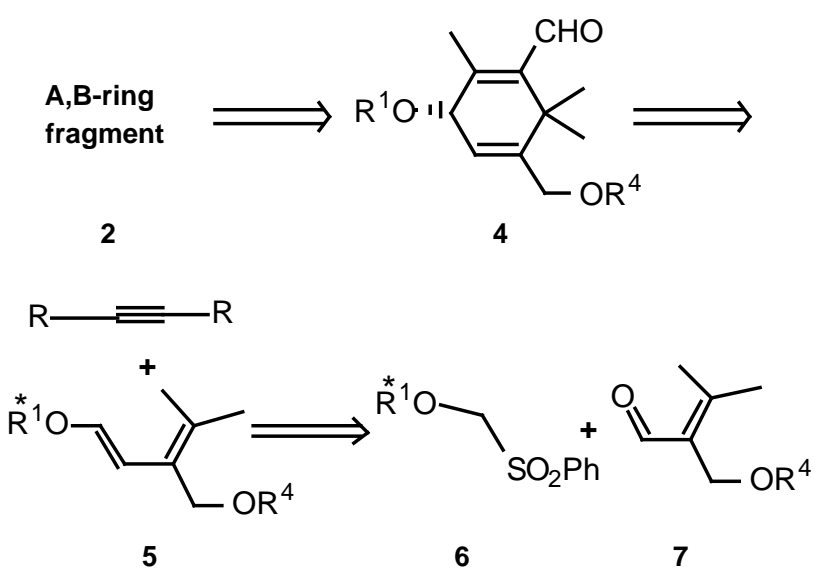

Scheme 2.
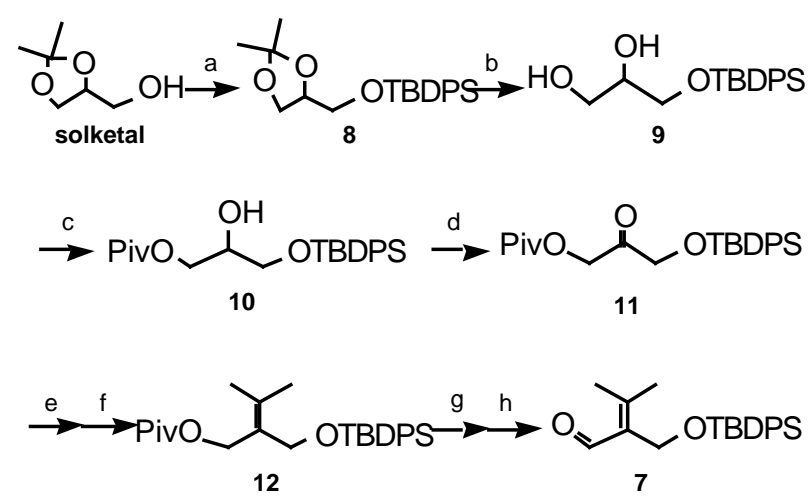

Scheme 3. Reagents and conditions: a) TBDPSCl, TEA, DMAP, $0^{\circ} \mathrm{C}$ then rt; $90 \%$; b) TFA, MeCN: $\mathrm{H}_{2} \mathrm{O}(4: 1)$, rt; 99\%; c) Piv-Cl, TEA, DMAP, $0^{\circ} \mathrm{C}$; 72\%; d) PDC, mol. sieves, rt; $71 \%$; e) $\mathrm{Me}_{2} \mathrm{C}(\mathrm{SeMe}) \mathrm{Li},-78^{\circ} \mathrm{C}$ to $\mathrm{rt} \mathrm{o} / \mathrm{n} ; 99 \%$; $)$ $\mathrm{PI}_{3}$, TEA, $0^{\circ} \mathrm{C} ; 56 \%$; g) DIBAL, $-78^{\circ} \mathrm{C} ; 84 \%$; h) $(\mathrm{COCl})_{2}$, DMSO, TEA, $-60^{\circ} \mathrm{C}$ to rt; $79 \%$.

Protection of the hydroxyl group of solketal as its TBDPS derivative, followed by unmasking of the diol and subsequent protection of the primary alcohol gave the compound 10, which was then oxidized to the ketone 11. Nucleophilic addition of $\mathrm{Me}_{2} \mathrm{C}(\mathrm{SeMe}) \mathrm{Li}$ [6] to the carbonyl group of the ketone $\mathbf{1 1}$ followed by reductive elimination of the resulting adduct gave the isopropenyl moiety of 12. Then, reduction of the ester and subsequent oxidation of the alcohol to the corresponding aldehyde gave the desired aldehyde 7 .

With this aldehyde in hand we examined options for the preparation of the above-mentioned chiral sulfones 6 . For this purpose, the alcohol 13 (Scheme 4) was considered to be an attractive starting material since it is commercially available as the racemic mixture as well as in both of the enantiomerically pure forms. Also, it would 
result in a benzyl protected alcohol which can be differentiated from the alcohol already present in the molecule. Initial attempts to convert the alcohol $\mathbf{1 3}$ to the corresponding chloromethyl derivative by reaction with paraformaldehyde and hydrogen chloride [7] failed, so an alternative route was developed in order to prepare the sulfone 16. Racemic sec-phenylethyl alcohol 13 was protected as the corresponding MEM-derivative [8]. Reaction of 14 with $\mathrm{Me}_{2} \mathrm{BBr}$ [9] followed by addition of thiophenol gave the sulfide 15 [10]. Finally, oxidation under the usual conditions afforded the desired asymmetric sulfone 16.
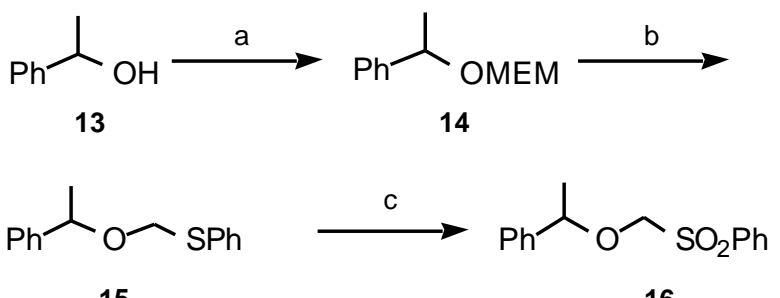

15

Scheme 4. Reagents and conditions: i) MEM-Cl, DIPEA, $\mathrm{rt} ; 86 \%$; ii) $\mathrm{Me}_{2} \mathrm{BBr},-78^{\circ} \mathrm{C}$, then DIPEA, $\mathrm{PhSH},-78^{\circ \circ} \mathrm{C}$; $99 \%$; iii) $\mathrm{NaOAc}, \mathrm{AcOOH}, 0^{\circ} \mathrm{C}$ to rt; $96 \%$.

Once the aldehyde 7 and the sulfone 16 had been successfully prepared the next step in our synthesis was to couple these two fragments in a Julia-type olefination reaction (Scheme 5). This initially gave the diastereomeric mixture of adducts $\mathbf{1 7}$, which were subjected to reductive cleavage of the sulfone and benzoate groups [11] to afford the desired diene $\mathbf{1 8}$ [12] as an E:Z mixture in a ratio of 9 to 1 .

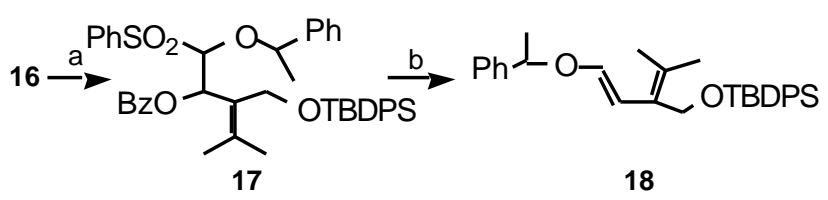

Scheme 5. Reagents and conditions: a) BuLi, $-78^{\circ} \mathrm{C}$, then aldehyde $7,-78^{\circ} \mathrm{C}$, then $\mathrm{BzCl},-78^{\circ} \mathrm{C}$ to $\mathrm{rt} ; 88 \%$; b) $\mathrm{SmI}_{2}$, THF, DMPU, rt; $90 \%$.

Thus, we had achieved the synthesis of the first chiral diene which would be used to investigate the asymmetric intermolecular Diels-Alder approach. To test the asymmetric induction of this diene 18, and, at the same time, avoid problems of regioselectivity in the reaction, the dimethyl ester of the acetylenedicarboxylic acid was chosen as a dienophile. The intermolecular Diels-Alder reaction was carried out at $140^{\circ} \mathrm{C}$ for 67 hours and afforded, in $80 \%$ yield, a mixture of diastereoisomers in a ratio of 7 to 3 (Scheme 6). This result proved the asymmetric induction of the diene was possible. It was impossible, however, to assign both diastereoisomers since they were inseparable by chromatogaphy. Fortunately, we found that reduction of the mixture of adducts 19 [13] to the mixture of lactones 20 [14] enabled easy separation of both diastereoisomers by flash chromatography. The major isomer was obtained as a crystalline solid, and X-ray analysis allowed us to unequivocally assign both compounds. Major 20, and therefore major 19 had the $R^{*}$, $R^{*}$ configuration.

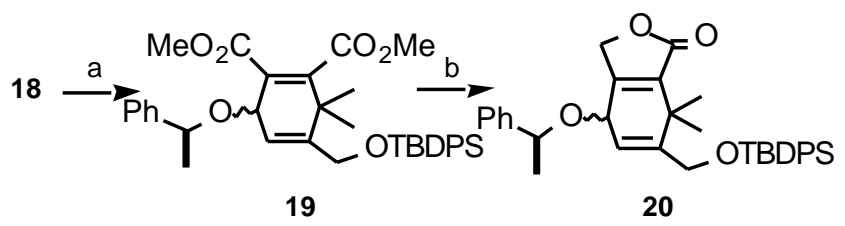

Scheme 6. Reagents and conditions: a) $2.5 \mathrm{M}$ in $\mathrm{PhMe}$, DMAD, $140^{\circ} \mathrm{C}, 67 \mathrm{~h} ; 80 \%$; b) LiAlH $(\mathrm{i}-\mathrm{Bu})_{2}(\mathrm{n}-\mathrm{Bu})$, THFhexane, $-30^{\circ} \mathrm{C} \mathrm{o} / \mathrm{n} ; 40 \%$.

After this encouraging Diels-Alder reaction, we explored the possibility of improving the asymmetric induction of the reaction by preparing a more hindered diene and one that was more electron-rich. Both dienes $(22$ and 24) were prepared following the synthetic route previously developed (Scheme 7). The diene 22 was synthesised in a comparable yield to the 18, whereas the sulfone $\mathbf{2 3}$ proved to be very sensitive and it was not possible to obtain the diene $\mathbf{2 4}$ as a pure compound in order to carry out the Diels-Alder reaction.
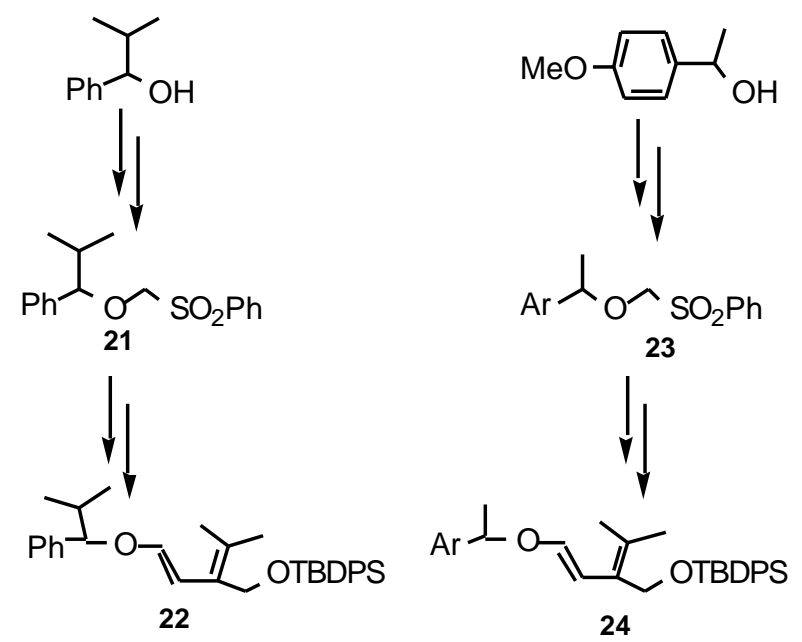

Scheme 7.

When the diene $\mathbf{2 2}$ was subjected to the same DielsAlder conditions as above (Scheme 8) the desired mixture of diastereoisomers 25 (7:3) were obtained. Unfortunately, 
no improvement in the selectivity of the reaction was observed and a considerable amount of material was lost due to the lower reactivity of this more hindered diene. Therefore, subsequent studies on the manipulation of the diesters were carried out using the initial mixture 19.

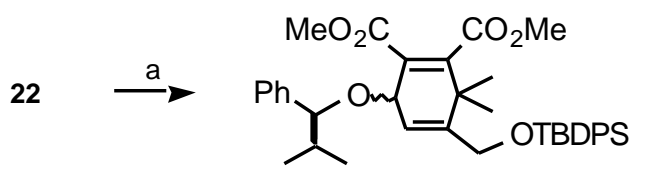

25

Scheme 8. Reagents and conditions: a) $2.5 \mathrm{M}$ in $\mathrm{PhMe}$, DMAD, $140^{\circ} \mathrm{C}, 67 \mathrm{~h} ; 49 \%$.

In order to obtain the above mentioned aldehyde 4 differentiation of the two ester groups in compound 19 was neccesary (Scheme 9). The possibility of reducing both ester groups to the corresponding diol and then selectively protecting one of them was investigated. However, after trying several reductions under varying conditions the diol could not be obtained. The only case of differentiation of the two ester groups observed was in the formation of the lactones 20 (Scheme 6).

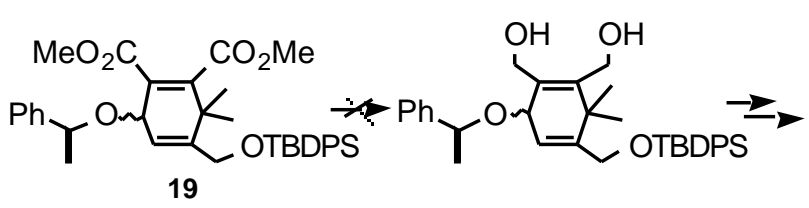

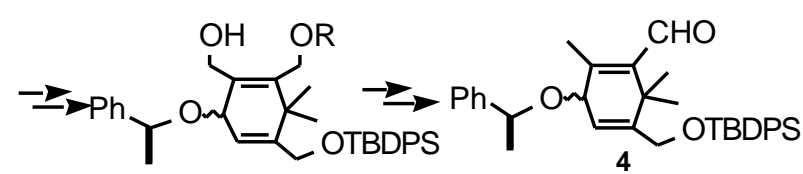

Scheme 9.

During the investigation of the selective ester reduction, we began to explore the preparation of the A,Bring fragment via an intramolecular Diels-Alder reaction (IMDA). We initially considered a relatively simple A,Bring fragment $\mathbf{2 6}$, that could be obtained by an intramolecular Diels-Alder reaction from 27 (Scheme 10).

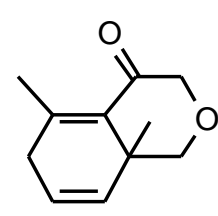

26

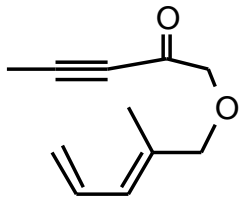

27
Scheme 10.
To prepare tethered molecule 27 we developed the synthetic route shown (Scheme 11). This route starts with a Wittig reaction between acrolein and the commercially available phosphorane 28. Reduction of the resulting unsaturated ester 29 afforded the alcohol 30. Coupling between this alcohol and $N$-methoxy- $N$-methyl-2-chloro acetamide [15] gave the corresponding adduct 31, which was converted into the aforementioned molecule 27 by Grignard addition. When a solution of $\mathbf{2 7}$ in toluene was heated at $162^{\circ} \mathrm{C}$ for 72 hours the expected Diels-Alder adduct 26 [16] was obtained. Unfortunately, this tethered molecule 27 was not very reactive and the IMDA adduct was obtained in only $5 \%$ yield, with remaining unreacted starting material.

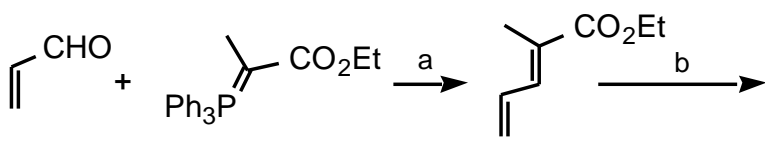

28

29

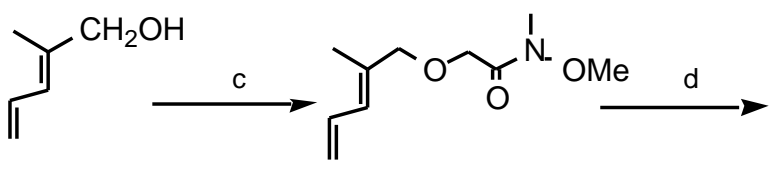

30

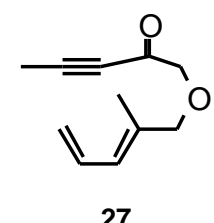

27

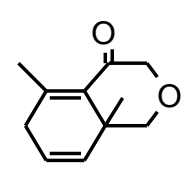

26
Scheme 11. Reagents and conditions: a) $\mathrm{CH}_{2} \mathrm{Cl}_{2}$, reflux; $70 \%$; b) DIBAL, $-78^{\circ} \mathrm{C}$; $91 \%$; c) $\mathrm{NaH}, \mathrm{Bu}_{4} \mathrm{NI}, N$-methoxy$\mathrm{N}$-methyl-2-chloro acetamide, DMF, rt; 60\%; d) 1 propynyl magnesium bromide, $-78^{\circ} \mathrm{C} ; 82 \%$; e) $\mathrm{PhMe}$, $162^{\circ} \mathrm{C}, 72 \mathrm{~h} ; 5 \%$.

Previous studies have shown that when a side-chain is present on the diene $\mathrm{C}-3$ in analagous intermolecular Diels-Alder reactions the reaction rate of the diene is significantly increased [17]. Therefore, in order to improve the yield of the IMDA reaction and at the same time introduce functionality that has to be present in the A-ring we decided to prepare the molecule 38, starting from the already known 2-methyltetronic acid 32 [18] (Scheme 12). The corresponding triflate 33 [19] was coupled with tributyl(vinyl)tin to give 34 [20] which was reduced [21] to the corresponding diol $\mathbf{3 5}$. We now intended to protect the hydroxyl group at C-9' and then apply the chemistry we had already developed in the previous scheme to the unprotected hydroxyl moiety. Initial studies using TBDPSCl as the protecting group gave a 1:1 mixture of the monoprotected alcohols, inseparable by chromatography. However, we found that after selective oxidation of 36, from the regioisomeric mixture of 
monoprotected diols, the separation was possible. The corresponding aldehyde was reduced to the alcohol and the sequence carried out only with the desired compound $\mathbf{3 6}$. Unfortunately, in the basic medium of the alkylation reaction the protecting group exchanged from one hydroxyl group to the other, regenerating the regioisomeric mixture.
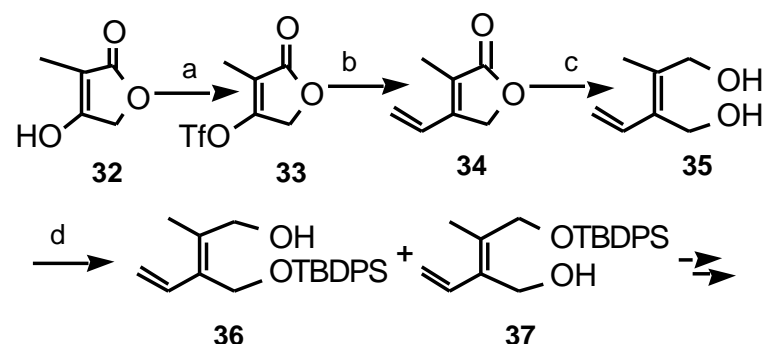

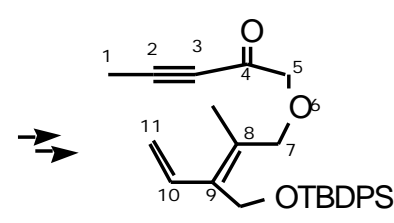

38

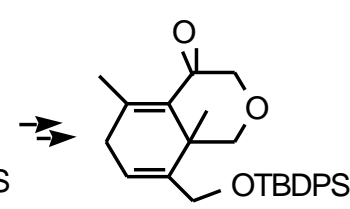

39
Scheme 12. Reagents and conditions: a) triflic anhydride, DIPEA, $\mathrm{CH}_{2} \mathrm{Cl}_{2},-78^{\circ} \mathrm{C} ; 92 \% ;$ b) tributyl(vinyl)tin, $\mathrm{Pd}\left(\mathrm{PPh}_{3}\right)_{4}$, THF, reflux; 91\%; c) DIBAL, Bz, $0^{\circ} \mathrm{C}$ then $\mathrm{rt}$; $60 \%$; d) $\mathrm{NaH}$, TBDPSCl, THF, $0^{\circ} \mathrm{C}$ then $\mathrm{rt} ; 50 \%$.

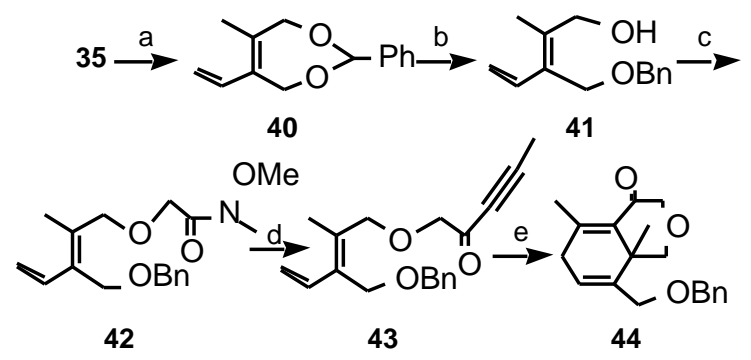

Scheme 13. Reagents and conditions: a) $\mathrm{PhCHO}$, p$\mathrm{TsOH}, \mathrm{Bz}$, reflux; 93\%; b) DIBAL, toluene, $0^{\circ} \mathrm{C}$ then $\mathrm{rt}$; $91 \%$; c) $\mathrm{NaH}, \mathrm{Bu}_{4} \mathrm{NI}, \mathrm{N}$-methoxy- $N$-methyl-2-chloro acetamide, DMF, rt; 74\%; d) 1-Propynyl magnesium bromide, $-78^{\circ} \mathrm{C}$; $45 \%$; e) $\mathrm{PhMe}, 166^{\circ} \mathrm{C}, 100 \mathrm{~h} ; 5 \%$

Eventually, the protection of the diol as the corresponding benzylidene acetal gave $\mathbf{4 0}$ in $93 \%$ yield (Scheme 13). Fortunately, we found that the reduction of this acetal using DIBAL was selective; only the desired alcohol 41 was obtained in $91 \%$ yield. Coupling between this alcohol and $N$-methoxy- $N$-methyl-2-chloro acetamide employing the conditions used previously gave compound 42. Addition of 1-propynyl magnesium bromide gave $\mathbf{4 3}$ in only $45 \%$ yield. Substantial decomposition was observed. Only a few attempts of the intramolecular Diels-Alder reaction have been carried out so far. Nevertheless, after heating a solution of $\mathbf{4 3}$ in toluene at $166^{\circ} \mathrm{C}$ for $100 \mathrm{~h}$ the desired Diels-Alder adduct 44 [22] was obtained.

In future work we hope to convert the IMDA adduct 44 into the A,B-ring fragment and also to improve the yield of the sequence by changing the benzyloxy group for a more stable protecting group. We also aim to prepare an asymmetric analogue of $\mathbf{4 3}$, which can then be used to prepare an asymmetric A,B-ring fragment 2.

Acknowledgements: This work was supported by the European Training and Mobility of researches under contract: ERBFMBICT 961460.

\section{References and Notes}

1. Wani, W. C.; Taylor, H. L.; Wall, M. E.; Coggon, P.; McPhail, A. T. J. Am Chem. Soc. 1971, 93, 2325.

2. (a) Nicolaou, K. C.; Yang, Z.; Liu J. J.; Ueno, H; Nantermet, P. G.; Guy, R. K.; Clairborne, C. F.; Renaud, J.; Couladouros, E. A. Paulvannan, K.; Sorensen, E. J. Nature 1994, 367, 630; Nicolaou. K. C.; Nantermet, P. G.; Ueno, H.; Guy, R. K.; Couladouros, E. A.; Sorensen, E. J. J. Am Chem. Soc. 1995, 117, 624; Nicolaou, K. C.; Liu, J. -J.; Yang, Z.; Ueno, H.; Sorensen, E. J.; Clairborne, C. F.; Guy, R. K.; Guy, R. K.; Hwang, C. K.; Nakada, M.; Nantermet, P. G. ibid. 1995, 117, 634; Nicolaou, K. C.; Yang, Z.; Liu, J. -J.; Nantermet, P. G.; Clairborne, C. F.; Renaud, J.; Guy, R. K.; Shibayama, K. ibid. 1995, 117, 645; Nicolaou, K. C.; Ueno, H.; Liu, J. -J.; Nantermet, P. G.; Yang, Z.; Rebaud, J.; Paulvannan, K.; Chadha, R. ibid. 1995, 117, 653; (b) Holton, R. A.; Somoza, C.; Kim, H. B.; Liang, F.; Biediger, R. J.; Boatman, R. D.; Shindo, M.; Smith, C. C.; Kim, S. C.; Nadizadeh, H.; Suzuki, Y.; Tao, C. L.; Vu, P.; Tang, S. H.; Zhang, P. S.; Murthi, K. K.; Gentile, L. N.; Liu, J. H. J. Am Chem. Soc 1994, 116, 1591; Holton, R. A.; Kim, H. B.; Somoza, C.; Liang, F.; Biediger, R. J.; Boatman, P. D.; Shindo, M.; Smith, C. C.; Kim, S. C.; Nadizadeh, H.; Suzuki, Y.; Tao, C. L.; Vu, P.; Tang, S. H.; Zhang, P. S.; Murthi, K. K.; Gentile, L. N.; Liu, J. H. ibid. 1994, 116, 1599; (c) Masters, J. J., Link, J. T.; Synder, L. B.; Young, W. B.; Danishefsky, S. J. Angew. Chem. Int. Ed. Engl. 1995, 34, 1723. For recent comprehensive collections of references to work in the area, see: Nicolaou, K. C.; Dai, W. -M.; Guy, R. K. Angew. Chem. Int. Ed. Engl. 1994, 33, 45; Paquette, L. A.; Thomson, R. C. J. Org. Chem. 1993, $58,4952$.

3. (a) Craig, D.; Fischer, D. A.; Kemal, O.; Marsh, A.; Plessner, T.; Slawin, A. M. Z.; Williams, D. J. 
Tetrahedron 1991, 47, 3095; (b) Craig, D.; Geach, N. J.; Pearson, C. J.; Slawin, A. M. Z.; White, A. J. P.; Williams, D. J. Tetrahedron 1995, 51, 6071; Clasby, M. C.; Craig, D. Tetrahedron Lett. 1992, 33, 3813; (c) Clasby, M. C.; Craig, D.; Marsh, A. Angew. Chem. Int. Ed. Engl. 1993, 32, 1444.

4. Ainsworth, P. J. ; Craig, D. ; Reader, J. C. ; Slawin, A. M. Z. ; White, A. J. P. ; Williams, D. J. Tetrahedron 1995, 51, 11601; Ainsworth, P. J.; Craig, D.; Reader, J. C.; Slawin, A. M. Z.; White, A. J. P.; Williams, D. J. Tetrahedron 1996, 52, 695; Craig, D.; Ford, M. J.; Stones, J. A. Tetrahedron Lett. 1996, 37, 535.

5. (a) Craig, D.; Munasinghe, V. R. N. Tetrahedron Lett. 1992, 33, 663; (b) Craig, D.; Munasinghe, V. R. N. $J$. Chem. Soc., Chem. Commun. 1993, 901; (c) Craig, D.; Pennington, M. W.; Warner, P. Tetrahedron Lett. 1993, 34, 8539; (d) Craig, D.; Pennington, M. W.; Warner, P. Tetrahedron Lett 1995, 36, 5815.

6. Rubenstein, S. M.; Williams, R. M. J. Org. Chem. 1995, 60, 7215 .

7. Connor, D. S.; Klein, G. W.; Taylor, G. N.; Boeckman, R. K.; Nedwid, J. B. Org. Synth. Coll. Vol. VI, 101

8. Corey, E. J.; Gras, J. L.; Ulrich, P. Tetrahedron Lett. 1976, $11,809$.

9. Noth, H.; Vahrenkamp, H. J. Organomet. Chem. 1968, 11, 399 .

10. (i) Morton, H. E.; Guindon, Y. J. Org. Chem. 1985, 50, 5379; (ii) Guindon, Y.; Yoakim, C.; Morton, H. E. J. Org. Chem. 1984, 49, 3912.

11. Ihara, N.; Suzuki, S.; Taniguchi, T.; Tokunaga, Y.; Fukumoto, K. Synlett 1994, 859.

12. Data of compound 18: $v_{\max }$ (film) $3069,3050,1648$, 1623, 1588, 1492, 1181, 1142, 1111, 1069, 759, 739 $\mathrm{cm}^{-1} ; \quad \delta_{\mathrm{H}}(300 \mathrm{MHz}) 7.64-7.24(15 \mathrm{H}, \mathrm{m}, \mathrm{Ph}+\mathrm{Ph}-\mathrm{Si})$, 6.63 (1H, d, J $\left.12.4 \mathrm{~Hz}, \mathrm{H}-5_{\text {maj }}\right), 5.96$ (1H, d, J 12.4 $\left.\mathrm{Hz}, \mathrm{H}-4_{\text {maj }}\right), 5.88$ (1H, d, J $\left.6.2 \mathrm{~Hz}, \mathrm{H}-5_{\min }\right), 4.93$ (1H, d, J $\left.6.2 \mathrm{~Hz}, \mathrm{H}-4_{\min }\right), 4.77(1 \mathrm{H}$, q, J $6.5 \mathrm{~Hz}$, $\left.\mathrm{PhCH}\left(\mathrm{CH}_{3}\right) \mathrm{O}_{\text {maj }}\right), \quad 4.70 \quad(1 \mathrm{H}, \quad \mathrm{q}, \quad \mathrm{J} \quad 6.5 \quad \mathrm{~Hz}$, $\left.\mathrm{PhCH}\left(\mathrm{CH}_{3}\right) \mathrm{O}_{\text {min }}\right), 4.52\left(1 \mathrm{H}, \mathrm{d}, \mathrm{J} 11.5 \mathrm{~Hz}, \mathrm{H}-3_{\text {min }}^{\prime}\right)$, $4.48\left(1 \mathrm{H}, \mathrm{d}, \mathrm{J} 11.5 \mathrm{~Hz}, \mathrm{H}-3^{\prime}{ }_{\min }\right), 4.25(1 \mathrm{H}, \mathrm{d}, \mathrm{J} 11.6$ $\left.\mathrm{Hz}, \mathrm{H}-3_{\text {maj }}\right), 4.18$ (1H, d, J $\left.11.6 \mathrm{~Hz}, \mathrm{H}-3_{\text {maj }}^{\prime}\right), 1.68$, $1.59\left(2 \times 3 \mathrm{H}, 2 \mathrm{~s}, \mathrm{H}-1+\mathrm{H}-2^{\prime}{ }_{\min }\right), 1.65,1.44(2 \times 3 \mathrm{H}, 2 \mathrm{~s}$, $\left.\mathrm{H}-1+\mathrm{H}-2_{\text {maj }}\right), \quad 1.53 \quad(3 \mathrm{H}, \quad \mathrm{d}, \quad \mathrm{J} \quad 6.5 \mathrm{~Hz}$, $\left.\operatorname{PhCH}\left(\underline{\mathrm{CH}}_{3}\right) \mathrm{O}_{\text {maj }}\right), \quad 1.40 \quad(3 \mathrm{H}, \quad \mathrm{d}, \quad \mathrm{J} \quad 6.5 \mathrm{~Hz}$, $\left.\mathrm{PhCH}\left(\underline{\mathrm{CH}}_{3}\right) \mathrm{O}_{\text {min }}\right), 1.04\left(9 \mathrm{H}, \mathrm{s}, \mathrm{SiC}\left(\mathrm{CH}_{3}\right)_{3 \min }\right), 0.95$ $\left(9 \mathrm{H}, \mathrm{s}, \mathrm{SiC}\left(\mathrm{CH}_{3}\right)_{3 \mathrm{maj}}\right) ; \delta_{\mathrm{C}}(75 \mathrm{MHz}$ ) (major isomer only) 146.4 (C-5), 143.0, 135.8, 133.9, 129.5, 129.1, 128.5, 127.5, $125.9(\mathrm{Ph}+\mathrm{Ph}-\mathrm{Si}+\mathrm{C}-2+\mathrm{C}-3), 107.2$ (C4), $\quad 78.9 \quad\left(\mathrm{PhC} H\left(\mathrm{CH}_{3}\right) \mathrm{O}\right), \quad 61.2 \quad\left(\mathrm{C}^{-3}\right), \quad 26.9$ $\left(\mathrm{SiC}\left(\mathrm{CH}_{3}\right)_{3}\right), 23.7\left(\mathrm{PhCH}\left(\mathrm{CH}_{3}\right) \mathrm{O}\right), 20.8\left(\mathrm{C}-1+\mathrm{C}-2{ }^{\prime}\right)$, $19.2\left(\mathrm{SiC}\left(\mathrm{CH}_{3}\right)_{3} ; \mathrm{m} / \mathrm{z}(\mathrm{CI}) 489\left[\mathrm{M}+\mathrm{NH}_{4}+\mathrm{H}\right]^{+}, 488\right.$ $\left[\mathrm{M}+\mathrm{NH}_{4}\right]^{+}, 471[\mathrm{M}+\mathrm{H}]^{+}, 470 \mathrm{M}^{+}, 366,309,232,215$, 111, 105 (Found: $\left[\mathrm{M}+\mathrm{NH}_{4}\right]^{+}, \quad 488.301177$. $\mathrm{C}_{31} \mathrm{H}_{38} \mathrm{O}_{2} \mathrm{Si}$ requires $\left.\left[\mathrm{M}+\mathrm{NH}_{4}\right]^{+}, 488.298483\right)$.

13. Kim, S.; Ahn, K. H. J. Org. Chem. 1984, 49, 1717.
14. Data of compound 20: $v_{\max }$ (film) 3048, 3030, 1750, $1472,1461,1280,1250,701 \mathrm{~cm}^{-1} ; \delta_{\mathrm{H}}(300 \mathrm{MHz})$ 7.52-7.30 $(15 \mathrm{H}, \mathrm{m}, \mathrm{Ph}+\mathrm{Ph}-\mathrm{Si}), 6.05(1 \mathrm{H}$, broad s, H5), 4.73 (1H, broad s, H-4), 4.68 (2H, s, H-3), 4.57 $\left(1 \mathrm{H}, \mathrm{q}, \mathrm{J} 6.4 \mathrm{~Hz}, \mathrm{PhC} \underline{\mathrm{H}}\left(\mathrm{CH}_{3}\right) \mathrm{O}\right), 4.31(2 \mathrm{H}$, broad s, H6'), 1.50 (3H, d, J $\left.6.4 \mathrm{~Hz}, \mathrm{PhCH}\left(\mathrm{CH}_{3}\right) \mathrm{O}\right), 1.28,1.14$ ( 2 x 3H, 2s, H-7'+H-7"), $1.08\left(9 \mathrm{H}, \mathrm{s}, \mathrm{SiC}\left(\mathrm{CH}_{3}\right)_{3}\right) ; \delta_{\mathrm{C}}$ (75 MHz) 171.9 (C-1), 156.7, 147.5, 143.8, 135.9, 134.4, 133.6, 130.2, 129.1, 128.7, 128.4, 128.1, 126.9, $126.8(\mathrm{Ph}+\mathrm{Ph}-\mathrm{Si}+\mathrm{C}-3 \mathrm{a}+\mathrm{C}-7 \mathrm{a}+\mathrm{C}-6), 118.1$ (C-5), 77.9, $67.7\left(\mathrm{C}-4+\mathrm{Ph} \underline{\mathrm{CH}}\left(\mathrm{CH}_{3}\right)_{3}\right), 69.7$ (C-3), $61.9(\mathrm{C}-6$ '), 34.9 (C-7), $27.2\left(\mathrm{SiC}\left(\mathrm{CH}_{3}\right)_{3}\right), 25.5,24.7,24.0(\mathrm{C}-7+\mathrm{C}-$ 7"+PhCH$\left.\left(\mathrm{CH}_{3}\right) \mathrm{O}\right), 19.7\left(\mathrm{SiC}\left(\mathrm{CH}_{3}\right)_{3}\right) ; \mathrm{m} / \mathrm{z}(\mathrm{CI}) 571$ $\left[\mathrm{M}+\mathrm{H}+\mathrm{NH}_{4}\right]^{+}, 570\left[\mathrm{M}+\mathrm{NH}_{4}\right]^{+}, 553[\mathrm{M}+\mathrm{H}]^{+}, 552 \mathrm{M}+$, 525, 512, 510, 508, 491, 465, 461, 274, 122 (Found $\left[\mathrm{M}+\mathrm{NH}_{4}\right]^{+}, \quad$ 570.304537. $\mathrm{C}_{35} \mathrm{H}_{40} \mathrm{O}_{4} \mathrm{Si}$ requires $\left[\mathrm{M}+\mathrm{NH}_{4}\right]^{+}$, 570.303963).

15. Maugras, I.; Poncet, J.; Jouin, P. Tetrahedron 1990, 46, 2807.

16. Data of compound 26: $v_{\max }$ (film) 3025, 1693, 1671, $1280,1159,1137,1110,966,719 \mathrm{~cm}^{-1} ; \delta_{\mathrm{H}}(400$ $\mathrm{MHz}) 5.73$ (1H, ddd, J 9.9, 4.2, $2.6 \mathrm{~Hz}), 5.48(1 \mathrm{H}$, ddd, J 9.9, 2.6, 0.8 Hz) (H-5+H-6), 4.19 (1H, d, J 16.5 Hz, H-2), 3.98 (1H, d, J 16.5 Hz, H-2), 3.65 (1H, d, J $11.0 \mathrm{~Hz}, \mathrm{H}-4), 3.63$ (1H, d, J $11.0 \mathrm{~Hz}, \mathrm{H}-4), 2.93(1 \mathrm{H}$, broad d, J 23.4 Hz, H-7), 2.73 (1H, broad d, J $23.4 \mathrm{~Hz}$, $\mathrm{H}-7), 2.06(3 \mathrm{H}, \mathrm{s}), 1.21$ (3H, s) (C-4a C $\left.\underline{\mathrm{H}}_{3}+\mathrm{C}-8 \mathrm{C}_{3}\right)$; $\delta_{\mathrm{C}}(75 \mathrm{MHz}) 198.8(\mathrm{C}-1), 143.1,133.1$ (C-8+C-8a), 130.1, 123.5 (C-5+C-6), 75.3, $75.2(\mathrm{C}-2+\mathrm{C}-4), 65.8$ (C-4a), 35.1 (C-7), 26.3, $20.9\left(\mathrm{C}-4 \mathrm{a} \underline{\mathrm{CH}}_{3}+\mathrm{C}-8 \underline{\mathrm{CH}}_{3}\right)$; $\mathrm{m} / \mathrm{z}$ (CI) $197\left[\mathrm{M}+\mathrm{H}+\mathrm{NH}_{4}\right]^{+}, 196\left[\mathrm{M}+\mathrm{NH}_{4}\right]^{+}, 179$ $[\mathrm{M}+\mathrm{H}]^{+}, 178 \mathrm{M}^{+}, 177,163,150,133,105$ (Found $[\mathrm{M}+\mathrm{H}]^{+}, 179.106865 . \mathrm{C}_{11} \mathrm{H}_{14} \mathrm{O}_{2}$ requires $[\mathrm{M}+\mathrm{H}]^{+}$, 179.107205).

17. The presence of a substituent at the diene C-3 presumably reduces the energy difference between the unreactive transoid and reactive cisoid conformations.

18. (a) Ramage, R.; Griffiths, G. J.; Shutt, F. E. J. Chem. Soc., Perkin Trans. I 1984, 1539; (b) Ramage, R.; Griffiths, G. J.; Shutt, F. E. J. Chem. Soc. Perkin Trans. I 1984, 1531.

19. Grigg, R.; Kennewell, P.; Savic, V. Tetrahedron 1994, $50,5489$.

20. Houpis, I. N. Tetrahedron Lett. 1991, 32, 6675.

21. Enas, J. D.; Shen, G.-Y.; Okamura, W. H. J. Am. Chem. Soc. 1991, 113, 3873.

22. Data of compound 44: $\delta_{\mathrm{H}}(400 \mathrm{MHz}) 7.40-7.30(5 \mathrm{H}$, m, Ph-H), 5.83 (1H, m, H-6), 4.51 (1H, d, J $10.7 \mathrm{~Hz}$, $\left.\mathrm{PhCH}_{2}-\mathrm{O}\right), 4.48\left(1 \mathrm{H}, \mathrm{d}, \mathrm{J} 10.7 \mathrm{~Hz}, \mathrm{PhCH}_{2}-\mathrm{O}\right), 4.18$ (1H, d, J $16.6 \mathrm{~Hz}, \mathrm{H}-2), 4.04$ (1H, d, J $11.3 \mathrm{~Hz}), 3.99$ (1H, d, J 16.6 Hz, H-2), 4.01 (1H, d, J $11.7 \mathrm{~Hz}), 3.97$ $(1 \mathrm{H}, \mathrm{d}, \mathrm{J} 11.7 \mathrm{~Hz}), 3.78(1 \mathrm{H}, \mathrm{d}, \mathrm{J} 11.3 \mathrm{~Hz})(\mathrm{H}-4+\mathrm{H}-$ 5'), 2.99 (1H, d, J $23.7 \mathrm{~Hz}, \mathrm{H}-7), 2.78$ (1H, dd, J 23.7, $4.6 \mathrm{~Hz}, \mathrm{H}-7), 2.09$ (3H, s), $1.30(3 \mathrm{H}, \mathrm{s})\left(\mathrm{C}-4 \mathrm{a} \mathrm{C} \underline{\mathrm{H}}_{3}+\right.$ C-8 $\left.\mathrm{CH}_{3}\right) ; \delta_{\mathrm{C}}(75 \mathrm{MHz}) 198.6(\mathrm{C}-1), 133.8$ (ipso-Ph), 128.5, 127.9 (ortho +meta +para Ph), 127.9 (C-6), 
$74.1, \quad 73.5, \quad 72.2, \quad 71.3 \quad\left(\mathrm{C}-2+\mathrm{C}-4+\mathrm{C}-5{ }^{\prime}+\mathrm{PhCH}_{2}-\mathrm{O}\right)$, 35.3 (C-7), 25.6, $21.5\left(\mathrm{C}-4 \mathrm{a} \underline{\mathrm{CH}}_{3}+\mathrm{C}-8 \underline{\mathrm{CH}_{3}}\right) ; \mathrm{m} / \mathrm{z}$ (CI) $316\left[\mathrm{M}+\mathrm{NH}_{4}\right]^{+}, 299[\mathrm{M}+\mathrm{H}] 283,274,257,242,222$,
205, 108, 91 (Found $\left[\mathrm{M}+\mathrm{NH}_{4}\right]^{+}, 316.191447$. $\mathrm{C}_{19} \mathrm{H}_{22} \mathrm{O}_{3}$ requires $\left.\left[\mathrm{M}+\mathrm{NH}_{4}\right]^{+}, 316.191269\right)$.

Sample Availability: Available from MDPI. 